\title{
Job Involvement and Occupational Stress among Female and Male Government Employees
}

\author{
Luhar Urmilaben Manubhai ${ }^{1}$, Dr. Krishnaben Vaghela ${ }^{2}$ \\ ${ }^{1}$ Research Scholar in Psychology, Saurashtra University, Rajkot, Gujarat-India \\ ${ }^{2}$ Associate Professor, Yogiji Maharaj Mahavidyalaya Mahila Arts and Commerce College Dhari, Gujarat - India
}

\begin{abstract}
The main purpose of this research was to find out the study of Job Involvement and Occupational Stress among female and male Government employees. For these Total 60 Government employees (30 female 30 male) were taken as a sample. The research tool for Job Involvement is developed by Lodhal and Kejner [1965] of Gujarati translate. While the tools for Occupational Stress was measured by psychologist A.K. Shrivastav \& Singh[1981]. Here t-test applied to check the significant difference of Job Involvement and Occupational Stress among Government employees [Female and Male]. Result revealed that significant difference Job Involvement among Female and Male Government employees. There is significant difference in Occupational Stress among Female and Male Government employees.
\end{abstract}

Keywords: Job Involvement and Occupational Stress

\section{Job Involvement and Occupational Stress}

Job involvement is the extent to which an individual identifies with one's job, i.e., the extent to which an employee thinks of one's job as an important part of one's self-concept. How significant the job is in defining who the employee is. How well a job projects one's self-image. The amount of time one is willing to consecrate towards one's job, towards its betterment and growth. It is the dedication with which one absorbs oneself in the job. Usually, there prevails a certain obscurity about the three terms: job involvement, job engagement and workaholism. However, these 11 terms have been discussed here to have their clear understanding. Job involvement in point of fact is different and in many ways superior than job engagement and workaholism. While job engagement is merely concerned with execution of an assigned job, job involvement depicts the dedication and sincerity with which an assigned job will be done. Workaholism is an addiction or obsession for work where the executives feel an innate compulsion to do it, but despite logging in an extraordinary amount of hours and sacrificing their health and loved ones for their jobs, workaholics are normally ineffective on their jobs. On the other hand, a job involved person exhibits devotion and loyalty towards the job and a keenness for efficient job completion. A job involved person wilfully spends considerable time on the job but accompanied with perseverance for precision. Job involvement is discernible by improved performance, productivity and profitability. It is also marked by readiness to take up extra work and devote additional time to it. Other perquisites attributable to job involvement include superior customer attention, security, better attendance and presence, improved retention, and by and large betterment of organization's welfare.

Occupational stress is defined as the harmful physical and emotional responses that occur when the requirements of the job do not match the resources, capabilities and needs of the worker (Alves, 2005; Lindholm, 2006). Stress is a complex concept which arises from interaction between an individual and the environment in which that individual exists. Thus, significant differences in occupational stress among health care workers may exist due to various work settings and levels of social support (Evans, 2002).Stress may be classified into Eustress and distress. Eustress is positive or good stress, whereas distress is the stress reactions to those events or actions appraised as being negative. Stress-related disorders encompass a broad array of conditions, including psychological disorders (e.g., depression, anxiety, posttraumatic stress disorder) and other types of emotional strain (e.g.,dissatisfaction, fatigue,tension, etc.),maladaptive behaviors(e.g., aggression, substance abuse), and cognitive impairment (e.g., conce-ntration and memory problems).In turn, these conditions may take the form of poor work Performance, higher absenteeism, less work productivity or even injury. Job stress is also associated with various biological reactions that may lead ultimately to compromised health, such as cardiovascular disease, or in extreme cases, even death. There are a total of 5 categories associated with occupational stress, Viz: 1. Factors unique to the job 2. Role in the organization 3. Career development 4. Interpersonal work relationships and 5. Organizational Structure/climat .These individual categories demonstrate that stress can occur specifically when a conflict stems from the job.

Thomas et al (2003) contend that job involvement is the degree to which a person is identified psychologically with his work, or the importance of work in his total self-image. Job involvement may also be thought of as the internalization of values about the goodness of work or the importance of work in the worth of the person, and perhaps it thus measures the ease with which the person can further be socialized by the organization. Begley and Cazjka (1993) are suggested that committed employees, because of their positive attitudes, are less distressed by occupational stressors and therefore they perceive less stress.

Occupational stress has been defined as a situation where occupation related factors interact with the employees in a manner that disrupts or enhances his/her physiological conditions forcing them to deviate from normal functioning 


\section{International Journal of Science and Research (IJSR) \\ ISSN (Online): 2319-7064}

Index Copernicus Value (2015): 78.96 | Impact Factor (2015): 6.391

(Jarvis 2002). Beehr and Newman (1978) defined occupational stress as "A condition arising from the interaction of people and their jobs and characterized by changes within people that force them to deviate from their normal functioning". Occupational stress is ubiquitous and increasingly costly Katherine et al (2008). Job satisfaction may be viewed as the pleasurable and emotional state resulting from theperception of one's job as fulfilling or allowing the fulfillment of one's important job values, provided these job values are compatible with one's need. Job satisfaction plays an important role as it has a positive impact on productivity, presence and performance. Therefore, the current study attempted to examine the associations between Job Involvement and Occupational Stress among Government employees.

\section{Review of Literature}

In the introductory paper the aim and scope of the present study has been discussed. This paper deals with the review of literature, which is an important aspect of any research. It helps to trace out the past trends in any particular branch of subject. The review of literature helps to identify the areas of research. There have been a lot of studies conducted to understand the relationship between job involvement and occupational stress both at national and international level. In this chapter various previous studies relating to involvement and occupational stress have been reviewed and how the present study differs from them are also discussed in detail.

\section{$>$ Study job Involvement:}

Kranti Walia, Sourabh Narang [2015] In order to gauge the well - being of professionals working in the IT industry, it is important to measure the levels of job stress experienced by them. This study attempted to ascertain the impact of various elements of job stress on job involvement in the IT sector. The sample for the study consisted of 117 professionals working in IT companies in three regions, that is, NCR region, Delhi, and Chandigarh. The findings highlighted that the sub variables of job stress that showed a significant negative correlation with job involvement were inter role distance, role stagnation, role overload, role isolation, and role ambiguity. In order to increase the job involvement level of employees, steps should be taken to minimize the ill effects of job stress by adopting various measures to enhance their work-life balance. Adopting personorganization-fit approach and offering challenging job roles to employees can be the managerial implications of the study.

M. Daniel Solomon: “Job Involvement and Job Stress among Employees at Private Sectors of Tiruchirappalli District" Of late, the global work scene has witnessed feisty efforts by managerial protagonists to revamp the jobs with a view to have amplified job involvement. This is apparently based on the belief that job involvement is conducive not only to efficiency but also employees' self-fulfilment. Work and the workplace accentuates many issues related to organizational psychology including job satisfaction, job involvement, quality of work life, motivation and leadership and the physical and mental health of workers. Job involvement and job stress have, therefore, emerged as an important set for research. The finding reveals that more than half 51.6 percent of the respondent have low level of Job involvement and less than half 484 percent of the respondent have high level of Job Involvement and while analyzing the stress level more than half 50. 8 percent of the respondent have low level of stress and less than half 49.2 have high level of stress.

\section{$>$ Study Occupational Stress:}

IPE Journal of Management[2014] 'Impact of Occupational Stress on the Relationship between Job Involvement and Motivation' The paper investigates the impact that job involvement (JI) has on the motivation (M) level of the industrial workers and also, finds out whether occupational stress (OS) moderates the relationship between job involvement and motivation. The study has been conducted on 315 employees belonging to different departments of Hindalco Industries Ltd., world's largest aluminium rolling company of Aditya Birla Group. Relationship between JI and $\mathrm{M}$ has been established with the help of $2 \times 2$ factorial design and moderation effect of occupational stress on the relationship between Job Involvement and Motivation has been checked with the help of Hierarchical Multiple Regression Analysis. The findings of the investigation have come out that $\mathrm{M}$ is positively related to JI. Also, OS does moderate the relationship between $\mathrm{JI}$ and $\mathrm{M}$ but in a negative way and the impact has been found to be moderate and significant.

M .Valan Rajkumar, R. Ilangovan and A .Velanganni Joseph [2016]: This paper focus on finding out, psychological test of job involvement, the perceived level of occupational stress and the job satisfaction among teachers in self financing engineering colleges affiliated to Anna University, Region III-Madurai. The enhanced feeling of involvement and satisfaction in the job would make the teachers have a positive attitude towards the teaching profession. The descriptive research design is used to conduct the research which describing the characteristics of a particular individual or of a group. The samples are collected from the universe, stratified random sampling is used, and to conduct this study 620 samples are collected out of 3015 teachers. For collecting the data, the questionnaire method is used. The data collected has been analyzed through the application of percentage analysis, ANOVA (analysis of variance) and TTest. Finally the researcher analyzed the data using SPSS (statistical package for the social science) 15.0 version and found that there is a considerable level of psychological test of job involvement, impact of job stress and job satisfaction on demographic variables among teachers. Hence the engineering colleges have to look forward to an improved sense job involvement with reduction of occupational stress and increases job satisfaction among the teaching faculty to extract the best out of them. So the management should take necessary steps to reduce occupational stress among teachers because it will result in increased job involvement, job satisfaction and quality of education.

\section{Research problem}

Job Involvement and Occupational Stress among female and male Government employees

\section{Volume 6 Issue 7, July 2017 www.ijsr.net}




\section{International Journal of Science and Research (IJSR) \\ ISSN (Online): 2319-7064}

Index Copernicus Value (2015): 78.96 | Impact Factor (2015): 6.391

\section{Objectives}

The main objectives of study were as under:

1) To measure the Job Involvement among female and male Government employees.

2) To measure the Occupational Stress among female and male Government employees.

\section{Null-Hypothesis}

To related objectives of this study null-hypothesis were as under:

1) There is no significant difference in Job Involvement among female and male Government employees.

2) There is no significant difference in Occupational Stress among female and male Government employees.

\section{Method}

\section{Participants:}

According to the purpose of present study total 60 samples has been selected. There were 30 female and 30 male Government employees. They were taken as a sample from different area in Amreli district.

\section{Instruments}

For this purpose the following test tool were considered with their reliability, validity and objectivity mentioned in their respective manuals. In present study two inventory used in research.

\section{1) Job Involvement scale:}

To check the Job Involvement scale was used. It is developed by Lodhal and Kejner [1965] of Gujarati translate. Total 20 statements in this scale, parting in two part very 'positive' and 'negative'. where in scale 13 sentence are positive items in sequentially format $1,2,3,4$, $5,6,7,8,9,11,12,15$ and 20 it marks measurement is $4,3,2$ and 1 . In have 7 sentence are negative items in sequentially format is $10,13,14,16,17,18$ and 19 it marks of measurement is $1,2,3$ and 4 . In this scale reliability score is ' $\mathrm{r}=0.73$ '. While scale reliability score is ' $\mathrm{t}$ ' test $=0.80$ '.

\section{2) Occupational Stress scale}

The scale was developed by psychologist A.K. Shrivastav \& Singh [1981]. Total 46 statements in this scale, parting in two part very 'positive' and 'negative'. In have positive sentence is $1,2,3,4,5,9,11,12,13,16,17,23,24,25,26$, $27,28,29,34,35,36,37,38,39,42,44,45$ and 46 it marks measurement is $5,4,3,2$ and 1 . In have negative sentence is $6,7,8,10,14,15,18,19,20,21,22,30,31,32,33,40,41$ and 43 it marks of measurement is 1, 2, 3, 4 and 5 .

\section{Procedure}

The testing was done on a group of female and male Government employees. . The whole procedure of fill the inventory was explained to them fully and clearly. The instructions given on the questionnaire were explained to them. It was also made clear to them that their scores would be kept secret. It was checked that none of the subjects left any questions unanswered of that no subject encircled both the answers given against question.

\section{Research Design}

The aim of present research was to a study of Job Involvement and Occupational Stress among female and male Government employees. For these total 30 female and male were taken as a sample. Here to measure Job Involvement scale by psychologist Lodhal and Kejner [1965] of Gujarati translate. While the tools for Occupational Stress scale by psychologist A.K. Shrivastav \&Singh [1981]. To check the difference between groups [female and male], t-test was used. The result and discussion of study is as under.

\section{Result \&Discussion}

The mean objective of present study was to study of Job Involvement and Occupational Stress among Government employees. In it statistical ' $t$ ' method was used. Result discussion of present study is as under.

Table 1: Showing means, S.D. and t-value of Job Involvement.

\begin{tabular}{|c|c|c|c|c|c|}
\hline Sr.No. & Sample Groups & $N$ & Mean & $S D$ & $T$ \\
\hline 1 & Female & 30 & 58.53 & 6.84 & \multirow{2}{*}{$2.11^{* *}$} \\
\hline 2 & Male & 30 & 55.17 & 5.44 & \\
\hline
\end{tabular}

$* \mathrm{P}<0.05=2.02$

$* * \mathrm{P}<0.01=2.71$

Significant level $=0.05$ level Significant

According to table-1 the result obtained on the basic area of Job Involvement reveals significant difference in among female and male Government employees.

In Job Involvement received female high mean score 58.53 as compare male 55.17 (table-1). There has mean difference was 2.11. The ' $t$ ' value was 2.02 (table-1) there was 0.05 level significant difference of Job Involvement among female and male Government employees. So we can't that say first hypothesis was not accepted.

Table 2: Showing means, S.D. and t-value of Occupational

\begin{tabular}{|c|c|c|c|r|c|}
\hline Sr.No. & Sample Groups & $N$ & Mean & SD & $T$ \\
\hline 1 & Female & 30 & 125.4 & 21.57 & \multirow{2}{*}{$0.84 * *$} \\
\hline 2 & Male & 30 & 130.5 & 25.33 & \\
\hline
\end{tabular}

$* \mathrm{P}<0.05=2.02$

$* * \mathrm{P}<0.01=2.71$

Significant level $=0.05$ level not Significant

According to table- 2 the result obtained on the basic area of Occupational Stress reveals significant difference in among female and male Government employees.

In Occupational Stress received female low mean score 125.40 as compare male 130.50 (table-1). There has mean difference was 0.84 . The ' $t$ ' value was 2.02 (table-1) there was 0.05 level significant difference of Occupational Stress among female and male Government employees. So we can't that say second hypothesis was accepted. 


\section{International Journal of Science and Research (IJSR) \\ ISSN (Online): 2319-7064}

Index Copernicus Value (2015): 78.96 | Impact Factor (2015): 6.391

\section{Conclusion}

There were significant differences in Job Involvement among female and male Government employees. There were significant differences in Occupational Stress among female and male Government employees.

\section{Limitation}

In the research work taken sample was not achieved with concentration on particular area. The study was restricted to only female and male Government employees. There for other female and male in not affected with the result. The present research includes 60 samples. So generalization of the result might be unfelt here. No other mental except questionnaires had been adopted in the present research work for the collection of information. In sample selection this random method was followed. The present research in only a part of the study, thus generalization should not be consummated, the scientific in not approached in the selection of sample. The conclusions of the present research are significant so one aspect the limitation reveals that both Job Involvement and Occupational Stress among Female and Male aspect of a person's (Women And Men) personality, character and occupation. There for in this practical world all people are taken differently and act differently. So it is inevitably complicated task to determine the proportion of Job Involvement and Occupational Stress among Female and Male in person's character and occupation.

\section{Suggestion}

Endeavour can be executed to analyze move them 60 data of sample with efficacy to attain better results. In this sample, we can use another scientific method, generate different result. For the accumulation of information, variegated methods except questionnaires can be adopted. Selection of sample can be accomplished with the intake of different people from different district to ascertain their Job Involvement and Occupational Stress among Female and Male. To crown the research work, other method of selecting sample can be appropriated.

\section{References}

[1] Alves, S. L. (2005). "A study of occupational stress, scope of practice, and collaboration in nurse anesthetists practicing in anesthesia care team settings", AANA Journal, 73(6), 443-452.

[2] Beehr, T. A. and Newman, J.E.[1978]: "Job stress, employee health and organizational effectiveness: A facet analysis", model and literature review, Personnel Psychology Vol.31, pp.665-699.

[3] Begley, T. M. and Cazjka, J. M. [1993] Panel analysis of the moderating effects of commitment on job satisfaction, intent to quit, and health following organisational change. Journal of Applied Psychology, Vol.78, pp.552-556.

[4] Evans, L. (2002). An exploration of district nurses' perception of occupational stress. British Journal of Nursing, 11(8), 576-585.
[5] IPE Journal of Management,[2014]: "Impact of Occupational Stress on the Relationship between Job Involvement and Motivation" IPE Journal of Management, Article - 6,July-Dec, 2014, Vol. 4, No. 2, (C) 2014, Institute of Public Enterprise.

[6] Jarvis, M. [2002]: Teacher stress: a critical review of recent findings and suggestions for future research directions. Teacher Support Network, Vol.14 (1).

[7] Katherine, P. E., George, J. A., Mary, B. and Linda, S. P. [2008]: "Stress Management in the Work Place", Journal of Computers in Human Behaviour, Vol.24 (2): pp.486-496,.

[8] Lindholm, M. (2006). Working conditions, psychosocial resources and work stress in nurses and physicians in chief managers positions. Journal of Nursing Management, 14(4), 300-309.

[9] Luhar Urmilaben M.[2015]:“A Study Of Occupational Stress, Job Involvement And Job Satisfaction Of Private And Public Employees" M.Phil. Dissertation, Department of Psychology Saurashtra University Rajkot.

[10] Praveena Thevisuthan [2017]: "The Relationship Between Occupational Stress And Job Involvement Of Doctors In Sri Lanka", International Journal of Research, Volume 04, Issue 01 January 2017.

[11]M. Daniel Solomon: Job Involvement and Job Stress among Employees at Private Sectors of Tiruchirappalli District", IOSR Journal Of Humanities And Social Science (IOSR-JHSS), e-ISSN: 2279-0837, p-ISSN: 2279-0845. PP 10-14, www.iosrjournals.org.

[12]M .Valan Rajkumar, R. Ilangovan and A .Velanganni Joseph [2016]: A Study on Job Involvement, Occupational Stress and Job Satisfaction among Teachers in Self-Financing Engineering Colleges in Anna University-Madurai Region, Engineering \& Technology in India com Vol. 1:5 December 2016, www.engineeringandtechnologyinindia.

[13] Thomas, N., Clarke, V. and Lavery, J. [2003]: Selfreported work and family stress of female primary teachers. Australian Journal of Education, Vol.47 (1), pp. $73-87$.

\section{Online Website}

[14] Chapter1:introduction,conceptual framework and review of literature, shodhganga.inflibnet.ac.in /bitstream/10603/8017/10/10_chapter\%201.pdf 